\title{
Choosing and siting food access interventions: Food mirages and produce stands in Portland, Oregon
}

\author{
Love Jonson * \\ University of Virginia
}

\begin{abstract}
Submitted February 11, 2016 / Revised April 14 and May 18, 2016 / Accepted May 23, 2016 /
Published online September 21, 2016

Citation: Jonson, L. (2016). Choosing and siting food access interventions: Food mirages and produce stands in Portland, Oregon. Journal of Agriculture, Food Systems, and Community Development, 6(4), 87-102. http://dx.doi.org/10.5304/jafscd.2016.064.011
\end{abstract}

Copyright (C) 2016 by New Leaf Associates, Inc.

\begin{abstract}
While Portland, Oregon, gains renown for supporting locally grown, sustainably produced, healthy, or otherwise "good" food, it has failed to ensure equitable access to said food. As parts of the city gentrify, dislocated Portlanders find themselves without access to fresh produce, contributing to health disparities among low-income and minority residents. This research sought to understand issues of food access among populations displaced by gentrification and determine the best locations for produce stands as a method to increase access to fresh produce. It examines the concept of the food mirage by studying the coverage of grocery stores in Portland and proposes an alternative intervention, produce stands, as a pedestrian-scale
\end{abstract}

\footnotetext{
* Bachelor of Urban and Environmental Planning, Department of Urban and Environmental Planning, University of Virginia. The author's address is 1035 SE 12th Avenue Apartment 19; Portland, Oregon 97214USA; +1-804-5130645; lovepjonson@gmail.com
}

approach to address gaps in grocery store accessibility for those without transportation. Calculations using geographic information systems (GIS) determine the ideal locations for produce stands in walkable areas not served by transit or fruit and vegetable markets and that house a high number of residents displaced by gentrification. The methodology returns appropriate sites in East Portland, a historically underserved area of the city facing disparities in obesity-related chronic disease. This paper contributes to the research and practice of food systems planning by incorporating indicators of gentrification-driven displacement as well as the built environment into a process of spatial analysis to expand consumption of affordable produce while providing entrepreneurship opportunities for disadvantaged residents. Food justice activists can use this methodology to determine areas of need and account for assets of the built environment in order to site a food access intervention that remains largely underutilized in North American cities. 


\section{Keywords}

Built Environment; Displacement; Food Access; Food Justice; Food Mirage; Food Systems; Food Systems Planning; Gentrification; GIS; Health Equity

\section{Introduction}

\section{Gentrification, Food Mirages, and Landing} Zones in Portland

Portland, Oregon, long known as a pioneering city in its efforts to support locally grown, sustainably produced food, is currently facing an influx of young urban professionals from across the country, due perhaps in part to its success in incorporating fresh food grown just outside its urban growth boundary. The gentrification of the city and the resulting rise in housing costs have pushed longstanding residents out of their central-city neighborhoods (Goodling, Green, \& McClintock, 2015). The degree to which an increase in access to healthy, sustainable, local, or otherwise "good" food drives gentrification and its sister phenomenon, displacement, remains in question (Hanser \& Hyde, 2014; Hyde, 2014). However, the changing cultural landscape brought by gentrification can dismantle the community's food system as sources of food evolve to fit the demands of new residents, leaving long-time residents feeling culturally alienated and unable to afford nutritious food (Anguelovski, 2014; Ocejo, 2014).

As outsiders flock to Portland for its high quality of life and reputation for sustainability, due in part to its booming food scene, many underprivileged Portlanders find themselves pushed out of their homes due to rising housing prices. Bates (2013) classified the stages of gentrification and displacement in Portland neighborhoods and identified certain areas as "landing zones," or neighborhoods to which displaced people move. These neighborhoods have seen an increase in the number of poor residents, ethnic minorities, and people with lower education levels. Landing zones mostly lie east of 82nd Avenue, a cultural and demographic dividing line that cuts through the city from north to south (Goodling et al., 2015). East Portland and North Portland contain dense regions of high-poverty neighborhoods with poor health outcomes, and they are home to a large percentage of the county's communities of color (Kristina Smock Consulting, 2014). African American, Latino, and American Indian populations in Multnomah County exhibit significantly higher obesity rates, and African Americans exhibit elevated mortality rates correlated with coronary heart disease, diabetes, and cancer (Fuller, 2014). In a review of the literature, Bell, Mora, Hagan, Rubin, \& Karpyn (2013) pinpoint lack of access to fresh produce as a key factor contributing to disparities in diet-related chronic disease among low-income populations.

While urban neighborhoods across the country house pockets of underserved residents who lack geographic access to full-service grocery stores that offer fresh produce and other healthy foods, Portland has flipped the phrase "food desert" on its head. Rather, Portland, a city known for its early innovation and support of local food systems, exemplifies a "food mirage." Originally expressed by Short, Guthman, and Raskin (2007) and expanded upon by Breyer and Voss-Andreae (2013), the term represents an area in which residents have geographic access to food sources but lack the economic or cultural means to take advantage of them. Indeed, low-income residents often travel outside their neighborhoods to purchase groceries at a lower price (LeDoux \& Vojnovic, 2014; Shannon, 2014; Walker, Fryer, Butler, Keane, Kriska, \& Burke, 2011), demonstrating that cost supersedes convenience in determining where to purchase food (Alkon, Block, Moore, Gillis, DiNuccio, \& Chavez, 2013; Barnes, 2005).

A neighborhood in Gresham, Oregon, immediately east of Portland, exemplifies a food mirage in which residents travel outside their neighborhood to purchase groceries. Rockwood, one of the most racially and ethnically diverse neighborhoods that experiences some of the highest poverty rates in the region (Cuneo, 2014), houses a full-service Albertsons supermarket as well as other smaller full-service stores. Lowincome residents, however, report traveling over six miles (9.7 kilometers) to lower-cost sources, most frequently a WinCo store northwest of the neighborhood (see Figure 1). For residents with access to a personal automobile, the trip costs 


\section{Figure 1. Map of Grocery Store Coverage in Rockwood}

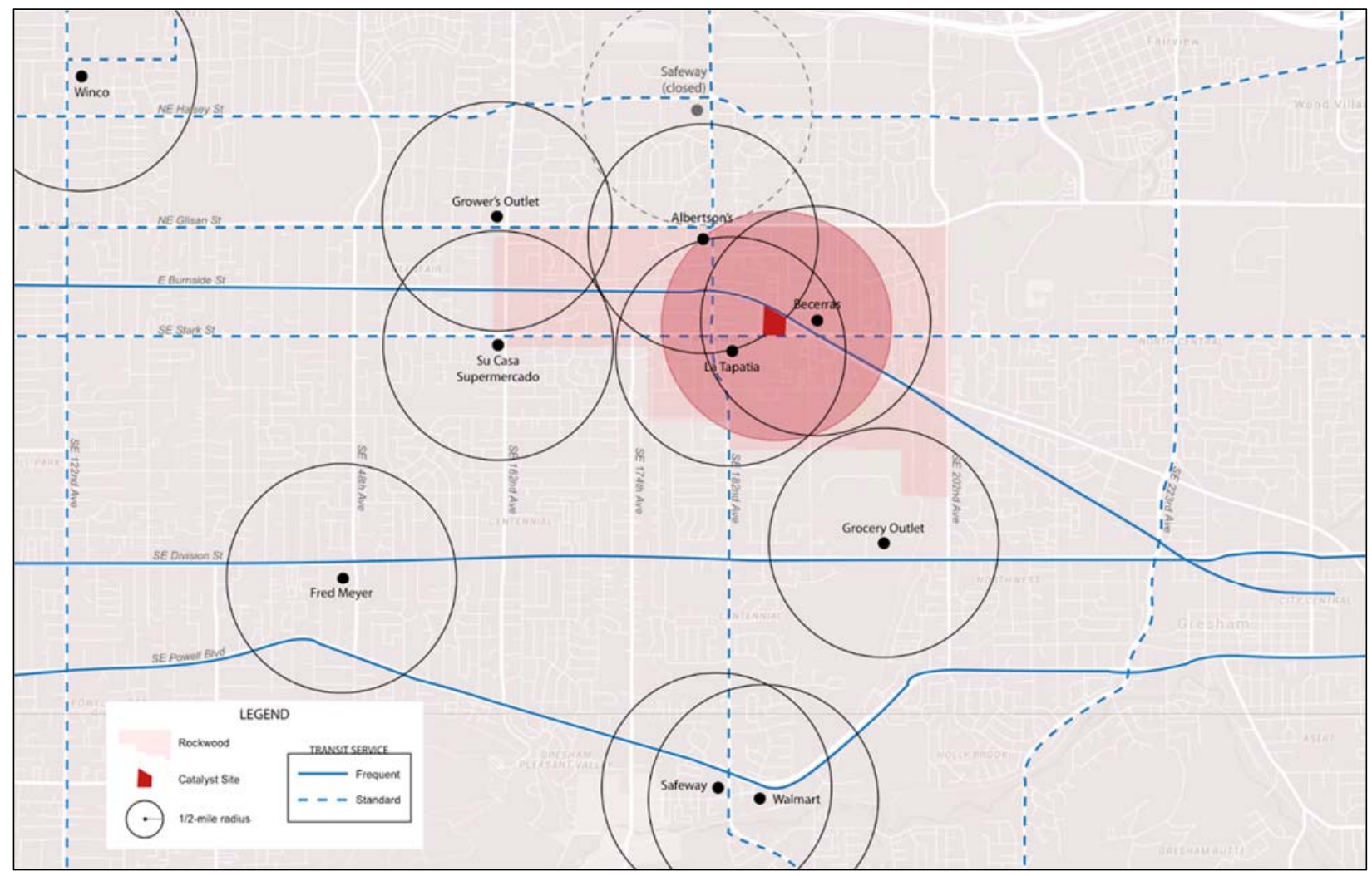

them time relative to a walkable food source. For residents without access to a car, a lack of northsouth transportation routes can extend the trip by hours or render it infeasible (Cuneo, 2014). The focus on the grocery store as panacea proves inadequate for communities like Rockwood, in which residents have geographic access to grocery stores but still face economic barriers that render food inaccessible.

\section{Alternative Intervention: Produce Stands}

Inequities in access to nutritious food despite nearcomprehensive geographic coverage of grocery stores in Portland suggest that considering grocery stores as the only or primary source of fresh food is problematic. First, in addition to taking advantage of lower prices for nutritious foods, supermarket shoppers also take advantage of lower prices to increase their purchases of unhealthy, processed foods at supermarkets (LeDoux \& Vojnovic, 2014). Concerns about this have led to calls for greater emphasis on the types of food offered at various sources when mapping food access (Van Hoesen, Bunkley, \& Currier, 2013). Furthermore, because low-income residents purchase food from sources other than supermarkets, such as small-scale grocers (Raja, Ma, \& Yadav, 2008), convenience stores, discount grocers, ethnic markets, food co-ops (Shannon, 2014), and mobile markets (Robinson, Weissman, Adair, Potteiger, \& Villanueva 2016; Widener, Metcalf, \& Bar-Yam, 2012, 2013; Zepeda \& Reznickova, 2013), a narrow focus on the supermarket as the benchmark for food access oversimplifies the food environment experienced by vulnerable populations. While some choose cost over convenience-exemplified by the Rockwood residents who drive six miles to a store with lower prices than the one in their neighborhood-those without the ability to travel by personal automobile or effective public transit are limited to the food sources in their immediate surroundings, whose fresh food may prove too expensive. The inability of nontransitory residents to search for the most 
affordable grocery store speaks to a need for a fine-grained, pedestrianscale intervention.

One enterprise that has seen success in other cities is the produce stand, which operates at a scale smaller than the supermarket and features only nutrient-dense foods. Portland has a small number of fruit and vegetable markets, but New York City's Green Carts program represents a new kind of food source that could flourish on Portland's walkable streets (see Figure 2). Produce stands are readily visible and convenient for people traveling to and from work by foot, bike, or transit. Their low infrastructure and overhead costs could support a program that offers produce at a low price coupled with acceptance of SNAP dollars. Identifying appropriate locations for produce stands could inform local farms with a food access mission, like Zenger Farms or Village Gardens Food Works in Portland, as well as similar organizations found across the country, of where they could be most effective. Produce stands also offer the potential for job creation for residents, offering an entrepreneurial opportunity to
Figure 2. Green Carts in New York City Offer Fresh Produce to Neighborhoods Lacking Access and Create Jobs for Local Residents

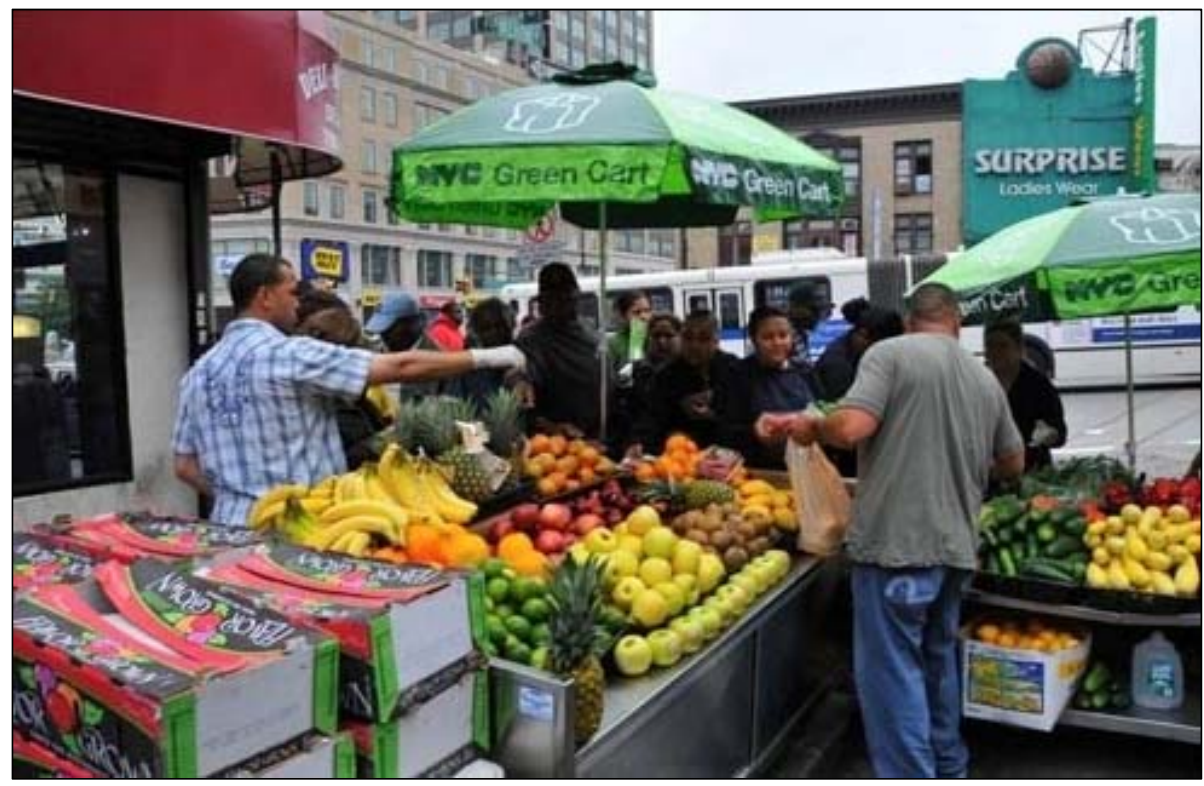

Photo credit: The Food Journal and Food, Nutrition, \& Science,

http://www.foodnutritionscience.com/articles/nycs-green-cart-initiative/

Figure 3. Context Map of Study Area

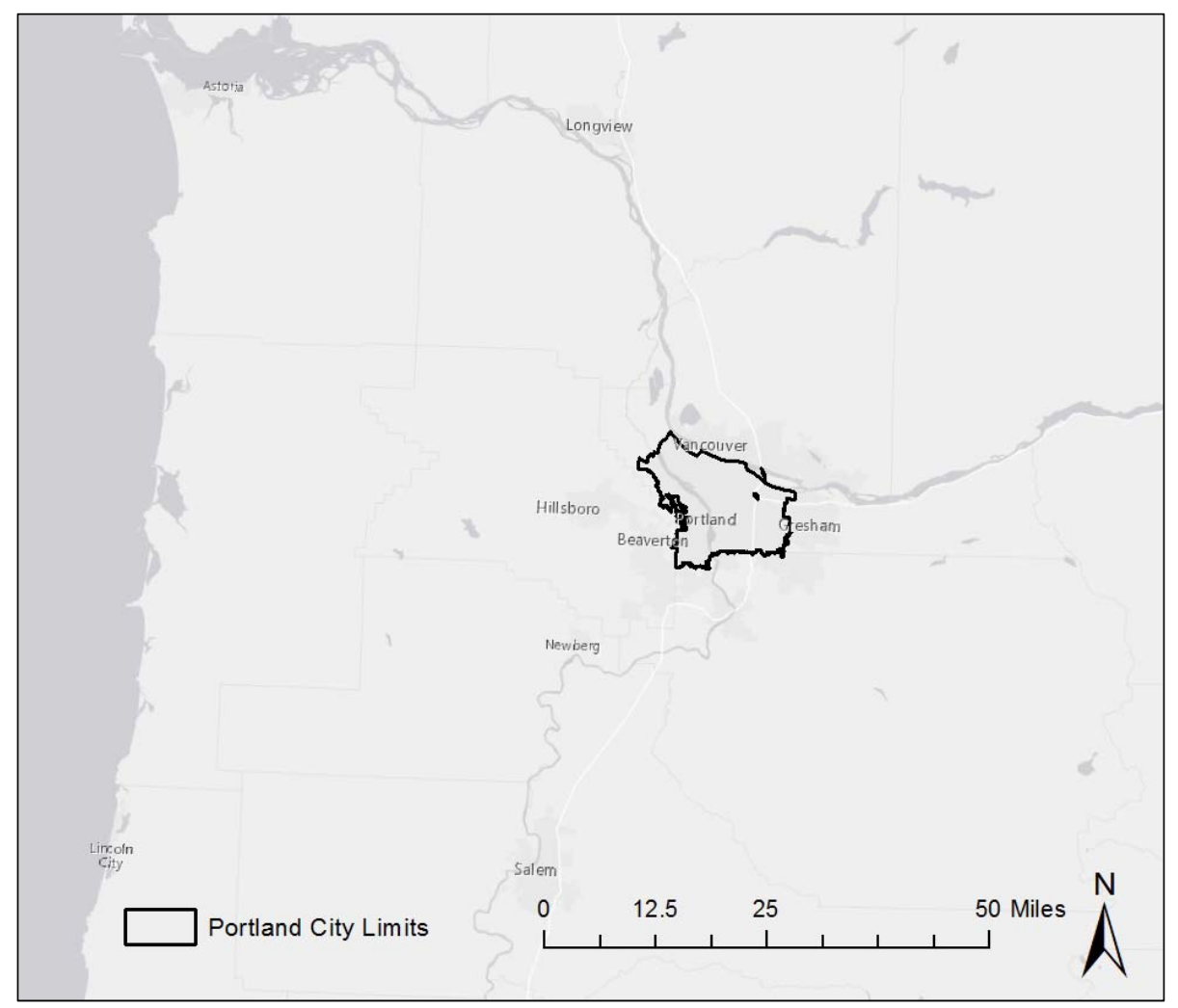


run a stand in their neighborhood (Fuchs, Holloway, Bayer, \& Feathers, 2014).

\section{Mapping Food Mirage Interventions}

This paper uses geographic information systems (GIS) to study geographic coverage of fruit and vegetable markets in addition to supermarkets in Portland, Oregon (see Figure 3), expanding upon previous analyses measuring food access (Grindal, Wilde, Schwartz, Klerman, Bartlett, \& Berman, 2016; Larsen \& Gilliland, 2008; LeClair \& Aksan, 2014; Luan, Law, \& Quick, 2015). It uses an alternative methodology to determine zones to which people displaced by gentrification move. Finally, it determines the ideal locations for produce stands to increase food access in the face of gentrificationdriven displacement, offering a methodology applicable to other cities experiencing inequities in food access not ameliorated by the presence of grocery stores.

\section{Methodology}

\section{Data Sources and Management}

Relevant data were acquired from the Portland-area Coalition for a Livable Future's Regional Equity Atlas (REA), a bank of tabular data relating to demographics, economic opportunity, built environment, and health outcomes; from Oregon Metro; from Esri Business Analyst; and from the City of Portland Bureau of Transportation.

After inserting all city boundaries from an Oregon Metro shapefile, all features except the Portland boundary were deleted, and the data frame was clipped to the boundary. Each data set was reprojected to the proper projected coordinate system, Oregon State Plane North, using the North American Datum of 1983 (National Adjustment of 2011) in international feet.

\section{Data Analysis}

\section{Demographic Indicators of Displacement}

Census tract-level data from the REA was used to determine which areas of Portland face the greatest influx of people displaced by gentrification. Three indicators (percentage change in population of color from 2000 to 2010, percentage change in median income from 2000 to 2010 , and percentage of households below the poverty level) predict areas classified as "landing zones" in the city. To bring the tabular data into spatial form, each spreadsheet from the REA was joined to a shapefile from Oregon Metro based on the field representing the census tract.

Next, the polygon vector features were converted to a raster with an output cell size of 20 feet $(6.1 \mathrm{~m})$ to show sufficient detail without creating an unmanageably large file. After converting the vector features to raster for each displacement indicator, layers were symbolized with a red-togreen color scale according to buckets suggested by the REA.

Finally, a raster calculation was performed to visualize areas of need based on the indicators of gentrification-driven displacement. Parts of the city deemed areas of need saw a positive change in the population of color, a negative change in median income, and greater than 15\% of households below the poverty line. Because areas that could be classified as landing zones would have a higher poverty rate than the average, a relatively low percentage for families living below the poverty level was used. Using the "and" operation in the raster calculator gave a more conservative estimate of landing zone areas than the "or" operation. The following calculation was used: ("PopColorRateChange_ Raster" > 0) \& ("PercentChangeMedianIncome_ Raster" < 0) \& ("PercentFamiliesBelowPoverty_ Raster" > .15).

\section{Bus Stop Service Areas}

Community food assessments in Rockwood revealed that a lack of north-south transit routes posed a challenge to residents without personal automobiles seeking affordable groceries (Cuneo, 2014). For this reason, the analysis sought to determine which areas of Portland were left with such transit gaps in order to site produce stands in those locations.

Conventional visualizations of transit coverage that show simple buffers around transit lines do not consider the importance of bus stops as the actual locations where people board transit. Instead of buffering bus lines or bus stops, the street network within a quarter-mile $(0.4 \mathrm{~km})$ radius around 
each stop was visualized. Showing a street-based service area recognizes that people cannot cross over yards or climb over buildings to get to a bus stop (Bell, 2015).

A shapefile of bus stop point locations from Oregon Metro was acquired. A quarter-mile (0.4 $\mathrm{km}$ ) buffer around each point was created and rasterized for inclusion in later raster calculations. Then street network data from Esri was intersected with the buffer to visualize the street network within a quarter-mile of each bus stop.

\section{Proximity to Food Sources}

Proximity to grocery stores was examined in order to test the food mirage hypothesis, while proximity to fruit and vegetable markets was examined to best site produce stands in areas lacking coverage. First, a shapefile of 2010 business locations from Esri Business Analyst was selected by attributes based on the city (Portland) and state (Oregon) using Federal Information Processing Standards (FIPS) codes. Supermarkets and other grocery stores as well as fruit and vegetable markets were identified based on the North American Industry Classification System (NAICS). NAICS defines supermarkets and other grocery stores as outlets retailing a line of food such as canned and frozen food; fresh fruits and vegetables; and fresh and prepared meats, fish, or poultry, excluding convenience stores (U.S. Census Bureau, 2012a). The NAICS definition of fruit and vegetable markets includes only establishments primarily selling fresh produce (U.S. Census Bureau, 2012b). Irrelevant listings on the layers were deleted based on personal knowledge verified by Internet searches, erasing listings for wholesalers without a retail outlet (e.g., Odwalla) or locations that do not sell fresh produce (e.g., Juicy Couture, Food and Water Watch).

Euclidean distance rasters for supermarkets and other grocery stores as well as for fruit and vegetable markets were created with an output cell size of 20 feet $(6.1 \mathrm{~m})$ and an environmental setting designating the city boundary as the extent. The output raster was then reclassified into five manual categories at quarter-mile $(0.4 \mathrm{~km})$ intervals.

\section{Siting Produce Stands}

Finally, a raster calculation incorporated measures of gentrification-driven displacement, bus stop coverage gaps, and proximity to fruit and vegetable markets in order to determine the areas in which to site produce stands (see Figure 4). The calculation found areas that (a) met the parameters for gentrification-driven displacement used above, (b) were not included within a quarter-mile $(0.4 \mathrm{~km})$ street network buffer around bus stops, and (c) were located more than a quarter-mile from food sources.

\section{Figure 4. Raster Calculator Expression Used To Determine Best Locations for Produce Stands}

("PopColorRateChange_Raster" > 0) \&

("PercentChangeMedianIncome_Raster" < 0) \&

("PercentFamiliesBelowPoverty_Raster" > .15) \& ("Distance from Fruit and Vegetable Markets" > 1320) \& (IsNull("BusStopBuffer_Raster"))

In order to further test the food desert/food mirage concept, a calculation was performed using supermarkets and other grocery stores as well as fruit and vegetable markets.

Finally, the street layer and a sidewalk shapefile from the City of Portland were overlaid. In addition to showing the sidewalk network onto which produce stands could locate, examining the sidewalk reveals gaps in coverage that could be addressed to improve the walkability of an area.

\section{Results}

\section{Demographic Indicators of Displacement}

Census tracts in the central parts of the city showed an increase in median household income from 2000 to 2010, while the steepest declines in median income occurred on the east and west ends of the city and, to a lesser degree, in North Portland. Northeast Portland, census tracts on the eastern edge, and a smattering of tracts across the inner east side showed the highest percentages of households in poverty. Finally, North and East Portland saw the greatest increases in population of color from 2000 to 2010 (see Figure 5).

The raster calculator incorporating the three indicators of gentrification-driven displacement returned areas of need primarily in North and East Portland (see Figure 6). 
Figure 5. Maps Showing Indicators of Gentrification-Driven Displacement in Portland

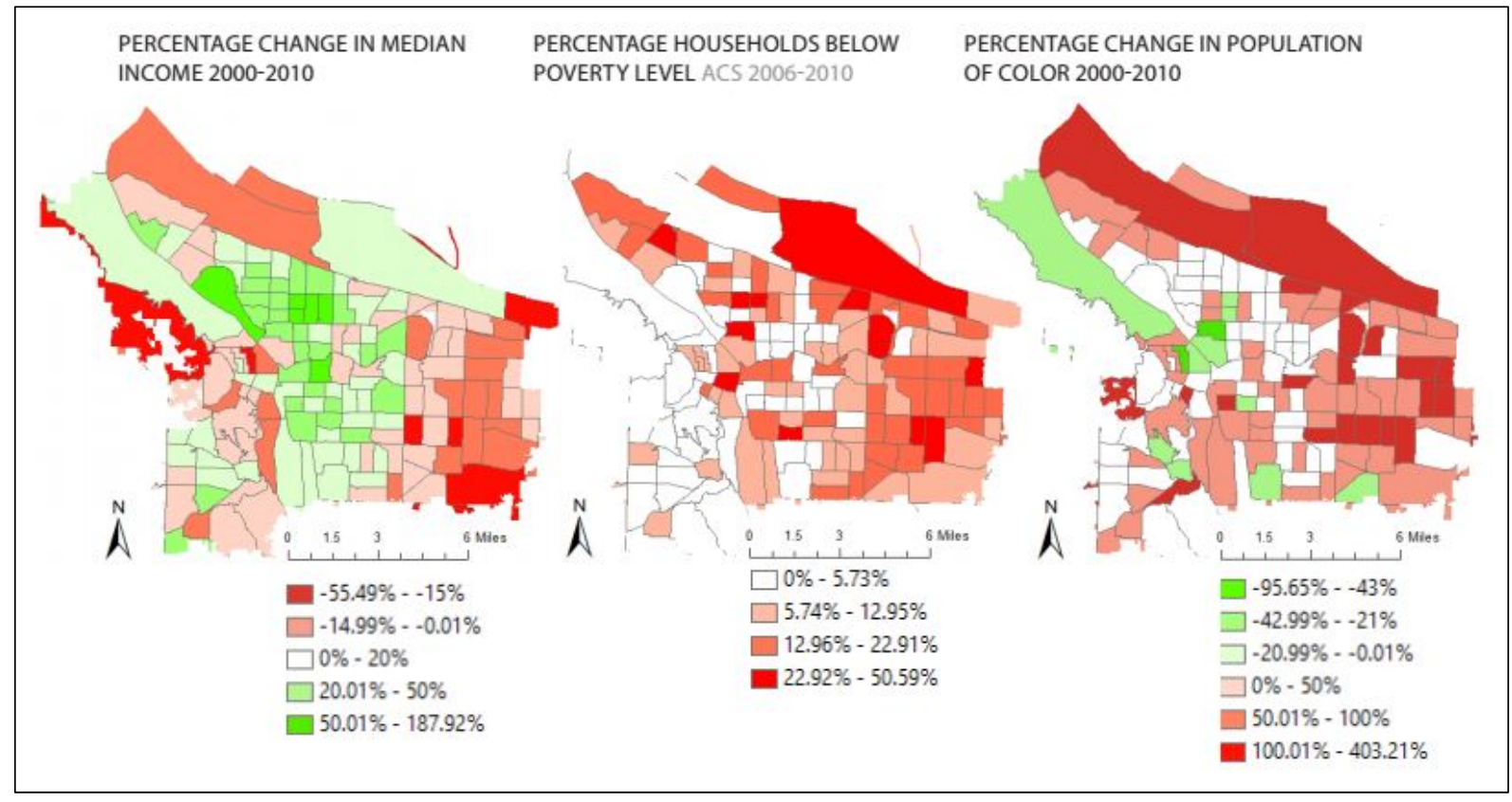

Figure 6. Areas of Need Based on Indicators of Displacement

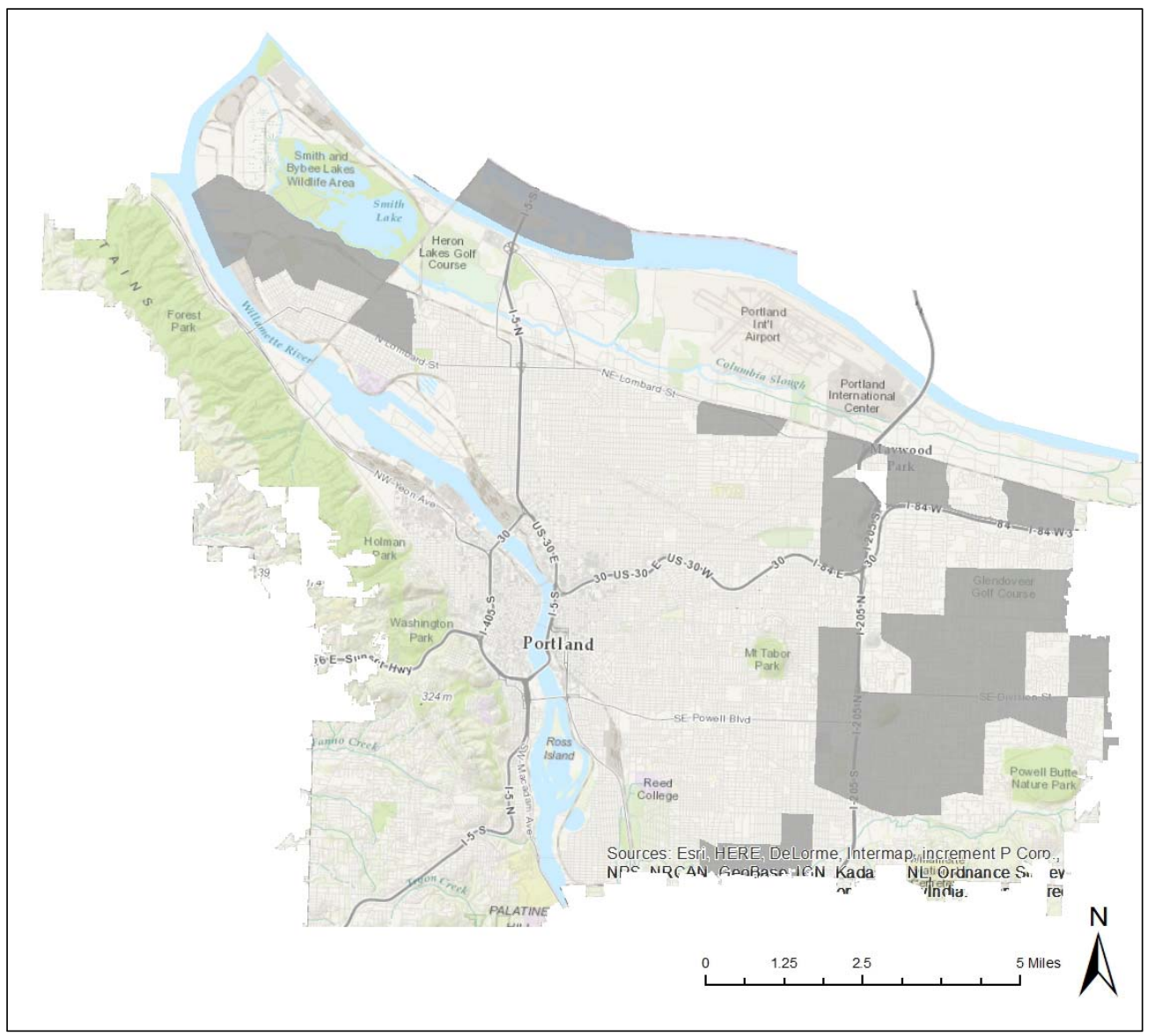




\section{Figure 7. Street Network Visualization of Bus Stop Service Areas with Detail of Coverage Gaps in East Portland}

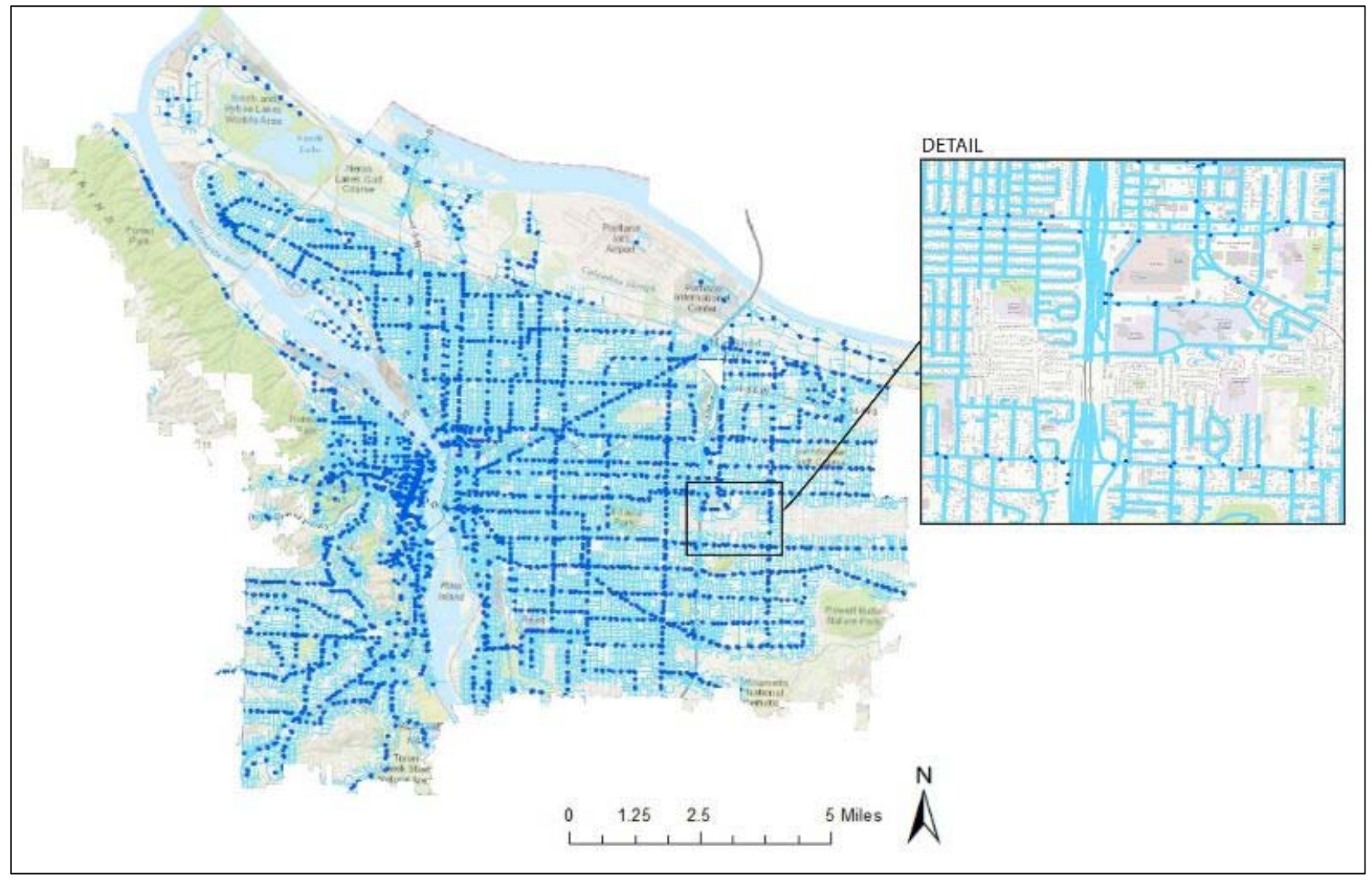

Bus Stop Service Areas

While most of the city enjoys coverage by bus lines, gaps in the street network served by bus stops exist in some parts of the east side (see Figure 7).

\section{Proximity to Food Sources}

The Euclidean distance raster of supermarkets and other grocery stores showed that an overwhelming majority of the city was covered by a one-mile (1.6 $\mathrm{km})$ radius around grocery stores. The only significant areas more than one mile from a grocery store, shown in purple on the map in Figure 8, represent Forest Park to the west, a golf course to the north, and Portland International Airport to the northeast. This supports the hypothesis that most of Portland does not represent a traditional urban food desert, in which people must travel over one mile to reach a grocery store.

The result for fruit and vegetable markets, however, tells a different story. A concentration of fruit and vegetable markets exists on the inner eastside, and markets exist sporadically across the rest of the city, but most of the city is not served by fruit and vegetable markets within a one-mile radius. More importantly, most of the city is not served by fruit and vegetable markets within a walkable quarter-mile radius (see Figure 9), leaving these areas ripe for on-street produce stands.

\section{Siting Produce Stands}

The final raster calculation to site produce stands returned no locations when incorporating the raster showing proximity to supermarkets and other grocery stores, meaning no gaps in grocery store coverage exist according to the parameters described above. This further supports the concept of the food mirage, in which issues of food access do not stem from geographic gaps in grocery store coverage. The calculation based on proximity to fruit and vegetable markets returned locations in North and East Portland that could benefit most 


\section{Figure 8. Proximity to Supermarkets and Other Grocery Stores}

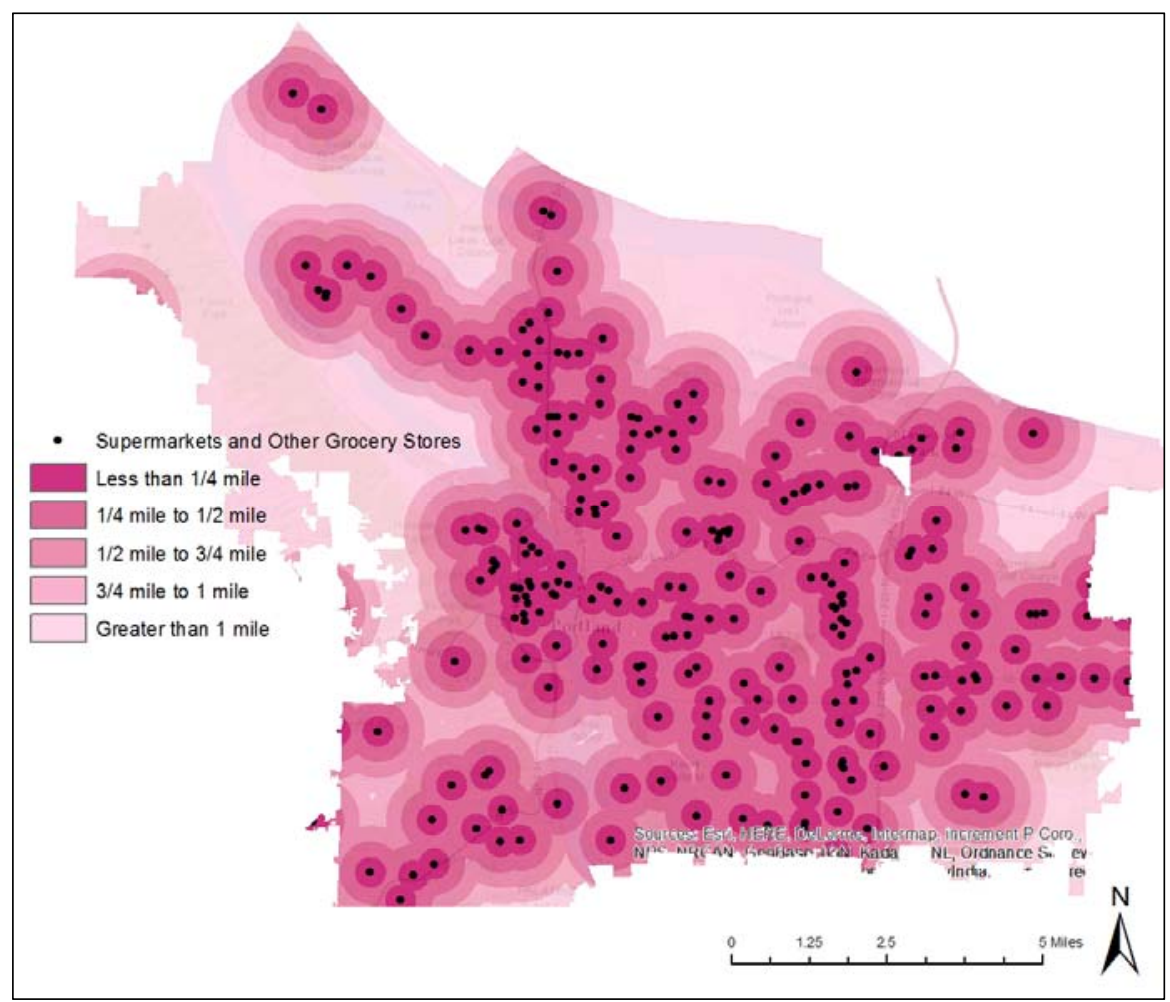

Figure 9. Proximity to Fruit and Vegetable Markets

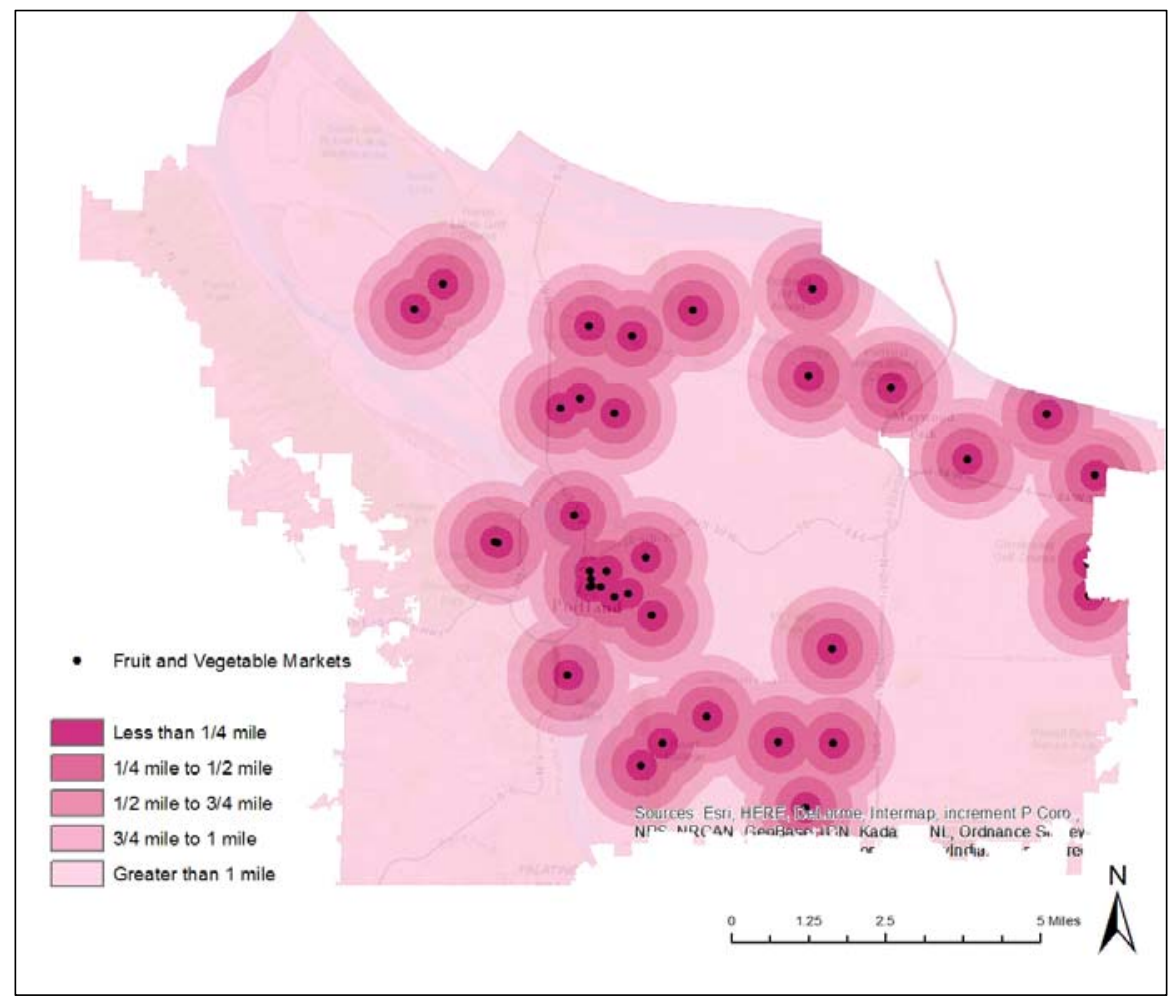

from on-street produce stands (see Figure 10).

The highlighted areas of North Portland, however, house mostly industrial and large-scale retail entities, leaving a potential produce stand without a significant customer base. On the other hand, all the selected areas in East Portland contain at least one school, ranging from a Head Start site to a high school, and three out of four contain at least one park. These community assets nestled in residential neighborhoods suggest that pedestrian traffic to and from schools or parks could likely support a produce stand (see Figures 11 through 14).

\section{Discussion}

After using spatial analysis to support the hypothesis that Portland does not represent a food desert, characterized by a lack of geographical access to grocery stores, but rather a food mirage, characterized by geographic accessibility coupled with economic and cultural barriers to fresh food, I posit that the city could support on-street produce stands as a method to partner with local farms with a mission to expand access for vulnerable Portlanders, especially those displaced by processes of gentrification. Improvements or adjustments to the outcomes found in this study could be realized by 
Figure 10. Potential Locations for Produce Stands to Increase Access to Fresh Food

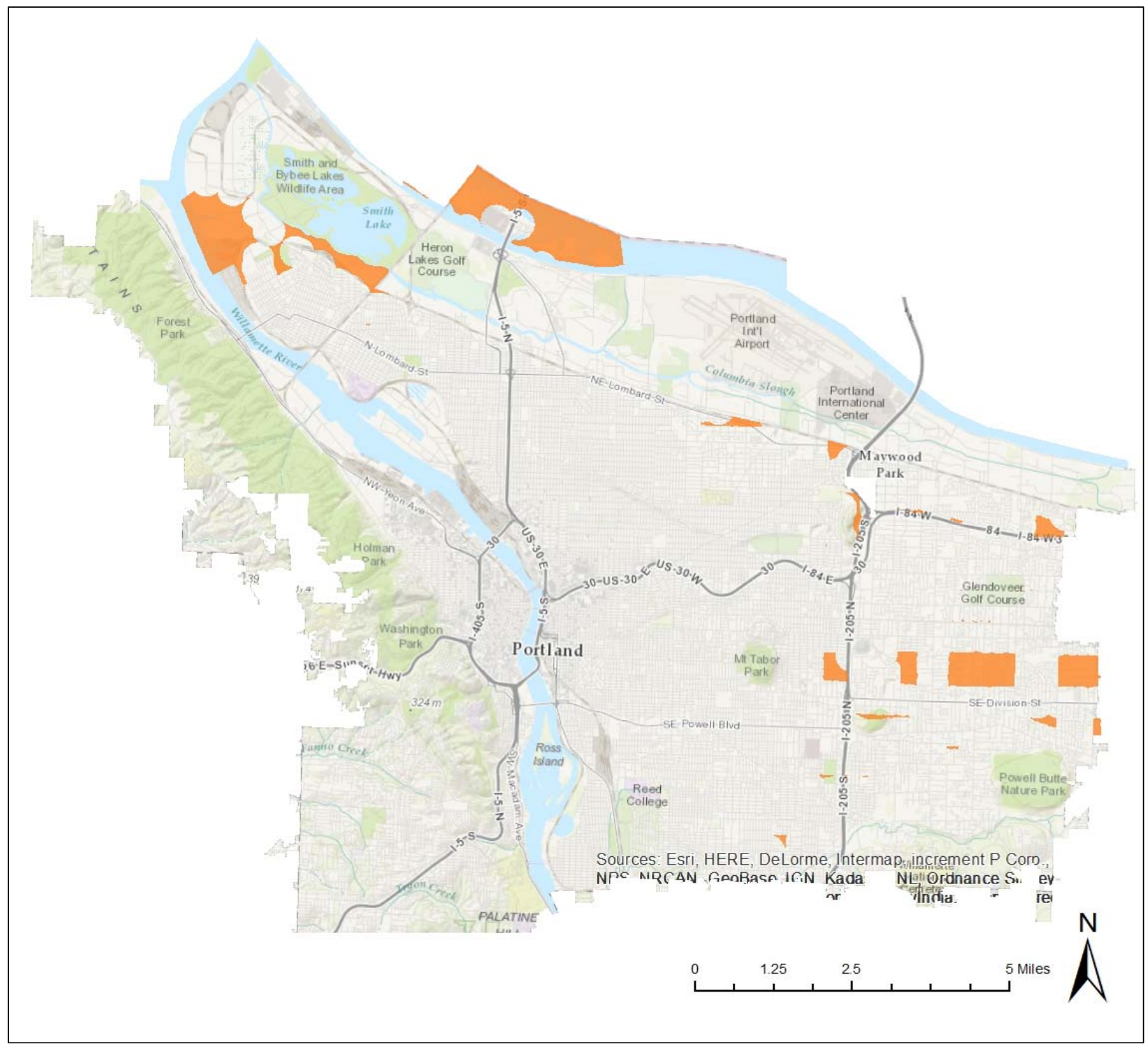

incorporating different types of data. The data chosen for this study were determined in part by the need for consistent geographies. Because there are numerous definitions and thresholds of poverty, gentrification, and displacement, choosing different measures will result in different, although still meaningful, results. Affordable housing organizations, for example, often focus on median area income rather than poverty levels; the Portland-area community land trust Proud Ground uses $80 \%$ of the median area income as a cutoff for the constituency it serves (Proud Ground, n.d.).
Housing value change could also provide a more direct measure of the effects of gentrification. Using these measures or others could result in more locations that could benefit from a produce stand.

While the relationship between gentrification and the growth in options for sustainable, locally produced, or otherwise "good" food in North American cities remains unclear, mounting evidence suggests that low-income and long-time residents are left behind as the cultural and economic foodscape changes around them 
Figure 11. Highlighted Area in Southeast Portland. This area from SE 88th Avenue to SE 94th Avenue and SE Salmon Street to SE Harrison Street contains Berrydale Park as well as the Creative Science School at Clark.

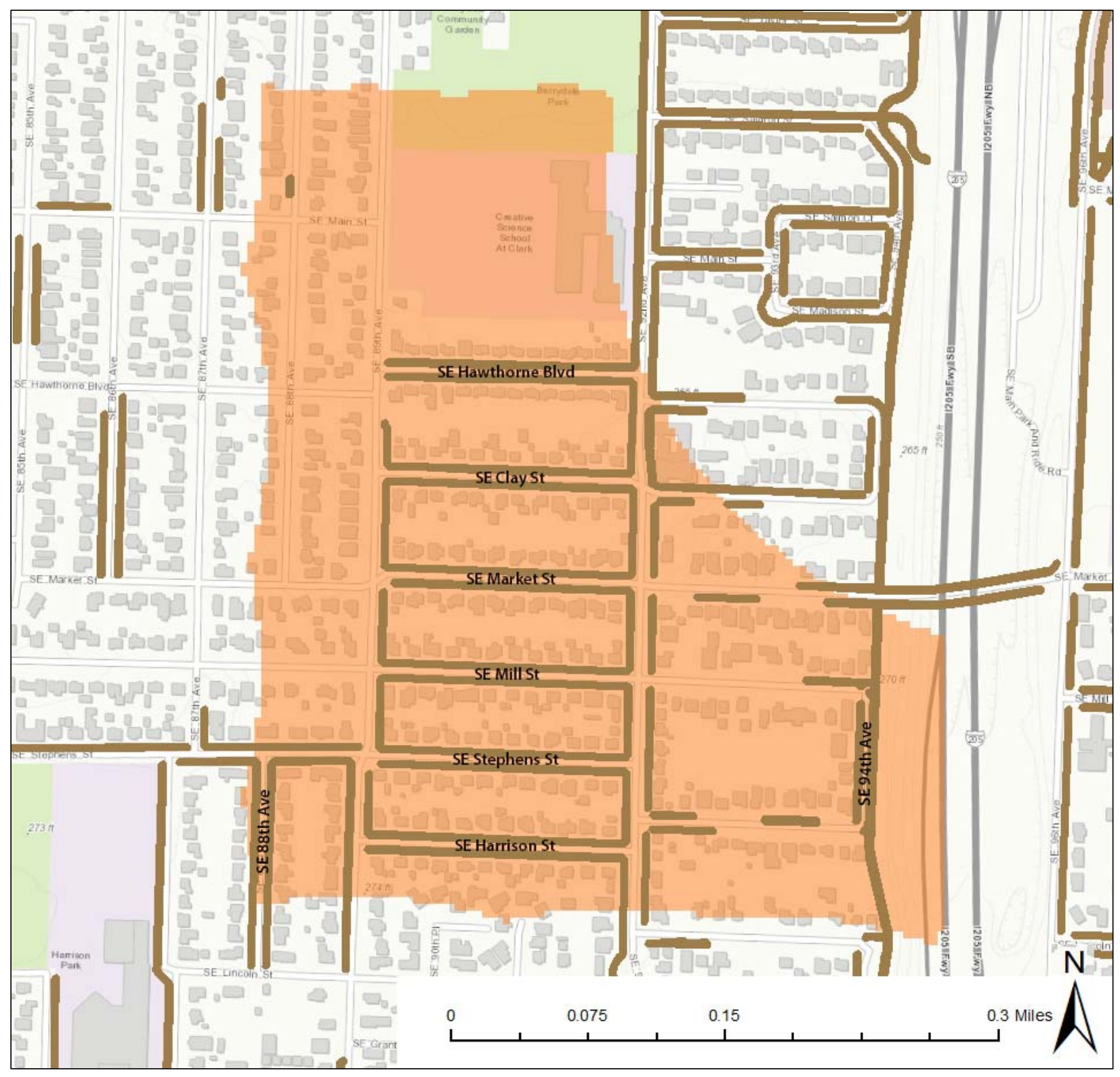

(Anguelovski, 2014; Hanser \& Hyde, 2014; Ocejo, 2014). This paper contributes to the discussion by focusing not on gentrification as a nebulous, unmeasured phenomenon but on the displacement of residents it can cause without an intentional policy to preserve affordability, using food access as a lens. It incorporates measures of gentrification-related displacement into a method of spatial analysis to site a food access intervention that could expand consumption of affordable produce while providing entrepreneurship opportunities for disadvan- taged residents, an opportunity that to date has been underutilized in many North American cities. Food justice activists can incorporate the methodology outlined in this paper to determine areas of need; account for assets of the built environment, such as the relationship among sidewalks, residences, and 
Figure 12. Highlighted Area in Southeast Portland. This area from SE 112th Avenue to SE 117th Avenue and SE Salmon Street to SE Lincoln Street contains Fir Ridge Campus, an alternative high school.

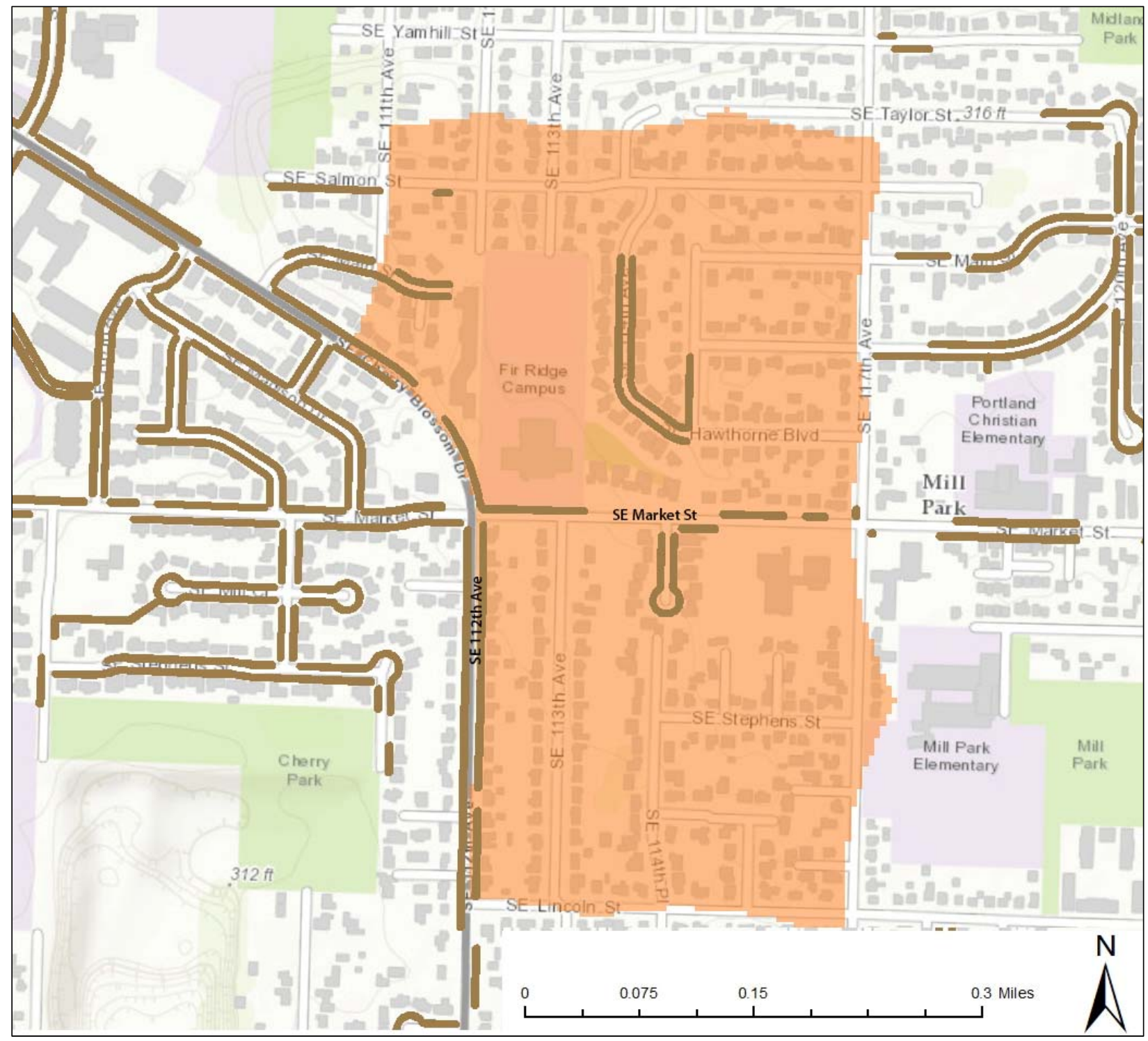

community centers; and identify assets of a community's food system, such as nonprofit urban or peri-urban farms in order to increase access to affordable produce in urban neighborhoods across the country.

\section{Conclusion and Future Directions}

This paper outlined a novel process to site produce stands as a food access intervention in neighborhoods seeing an influx of displaced residents in Portland, Oregon. It outlined the applicability of the methodology to other North American cities experiencing tensions between "good" food and gentrification, a complex interrelationship that urban neighborhoods will continue to navigate. Produce stands offer a fine-grained approach to support food access in walkable urban neighborhoods for residents requiring low-cost goods without the use of a personal automobile or public transportation. Future research could build support for the proposed intervention by determining ideal operating hours for food stands, in order to 
Figure 13. Highlighted Area in Southeast Portland. This area from SE 127th Avenue to SE 148th Avenue and SE Taylor Street to SE Lincoln Street contains Mill Park Preschool, North Powellhurst School, Lincoln Park Elementary, David Douglas High School, the Community Transition Program, Lincoln Park, and North Powellhurst Park.

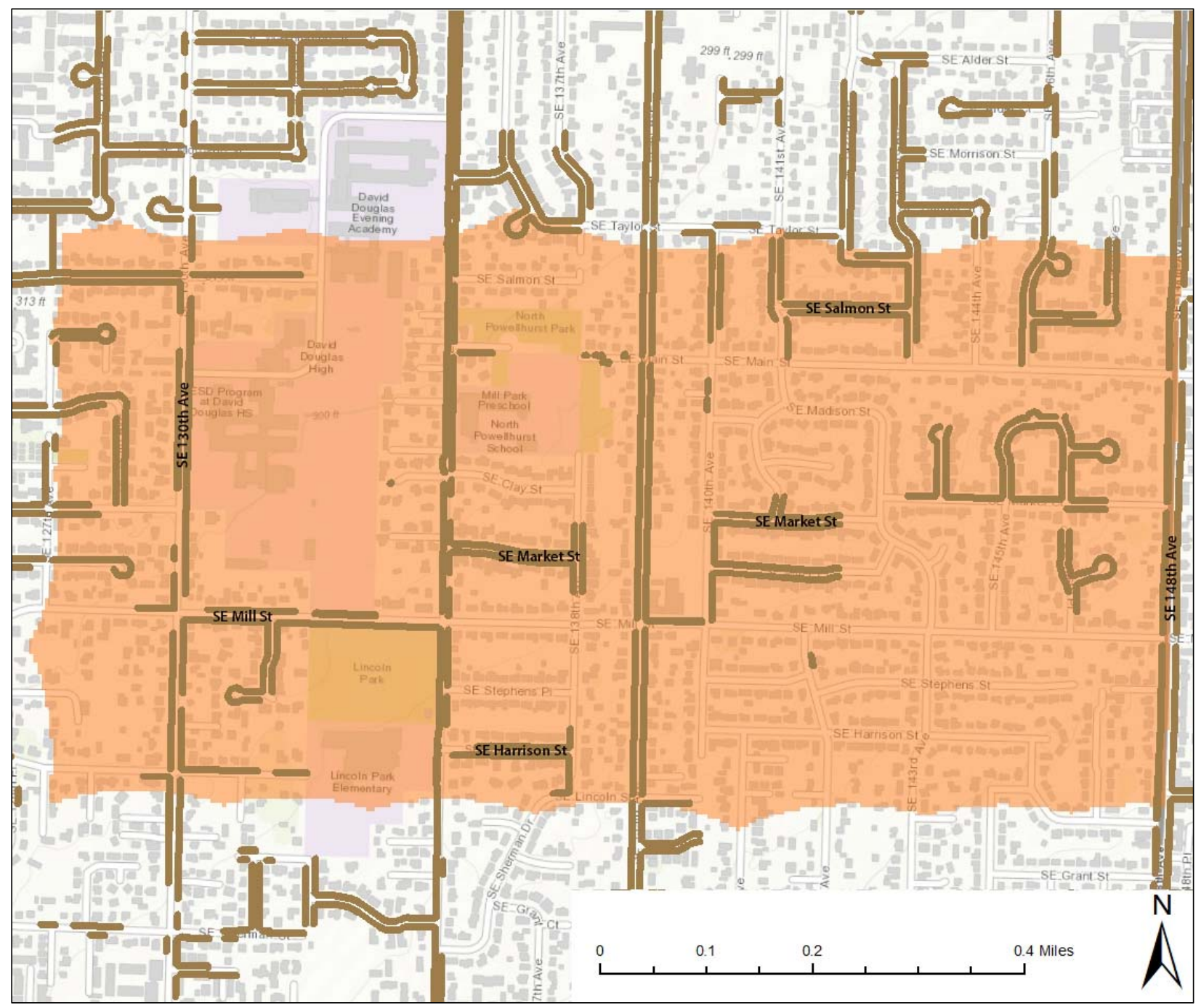

accommodate weekday, weekend, and evening shoppers. It could also explore the potential for expanding the product mix beyond fresh produce to include staple grains and sources of protein.

The spatial analysis performed in this paper expands the focus in conversations of food access beyond physical access to include financial access. However, diet-related health inequities exist not only due to a lack of access to fresh produce, whether defined geographically or economically. Cultural practices also determine the extent to which fresh produce becomes successfully incorporated into the diet. This research focused primarily on economic access to produce by using measures of gentrification-driven displacement as a proxy. In order to support the economic viability of local farmers growing at a small to medium scale, future research could determine effective funding mechanisms for programs focusing on food access. Further research could also dive deeper into the cultural barriers contributing to health inequities and their spatial determinants. Any intervention to increase access to nutritious food among underserved residents should emerge 
Figure 14. Highlighted Area in Southeast Portland. This area from SE 162nd Avenue to SE 174th Avenue and SE Salmon Street to SE Harrison Street contains Lynch View Elementary, a Head Start site, and Lynchview Park.

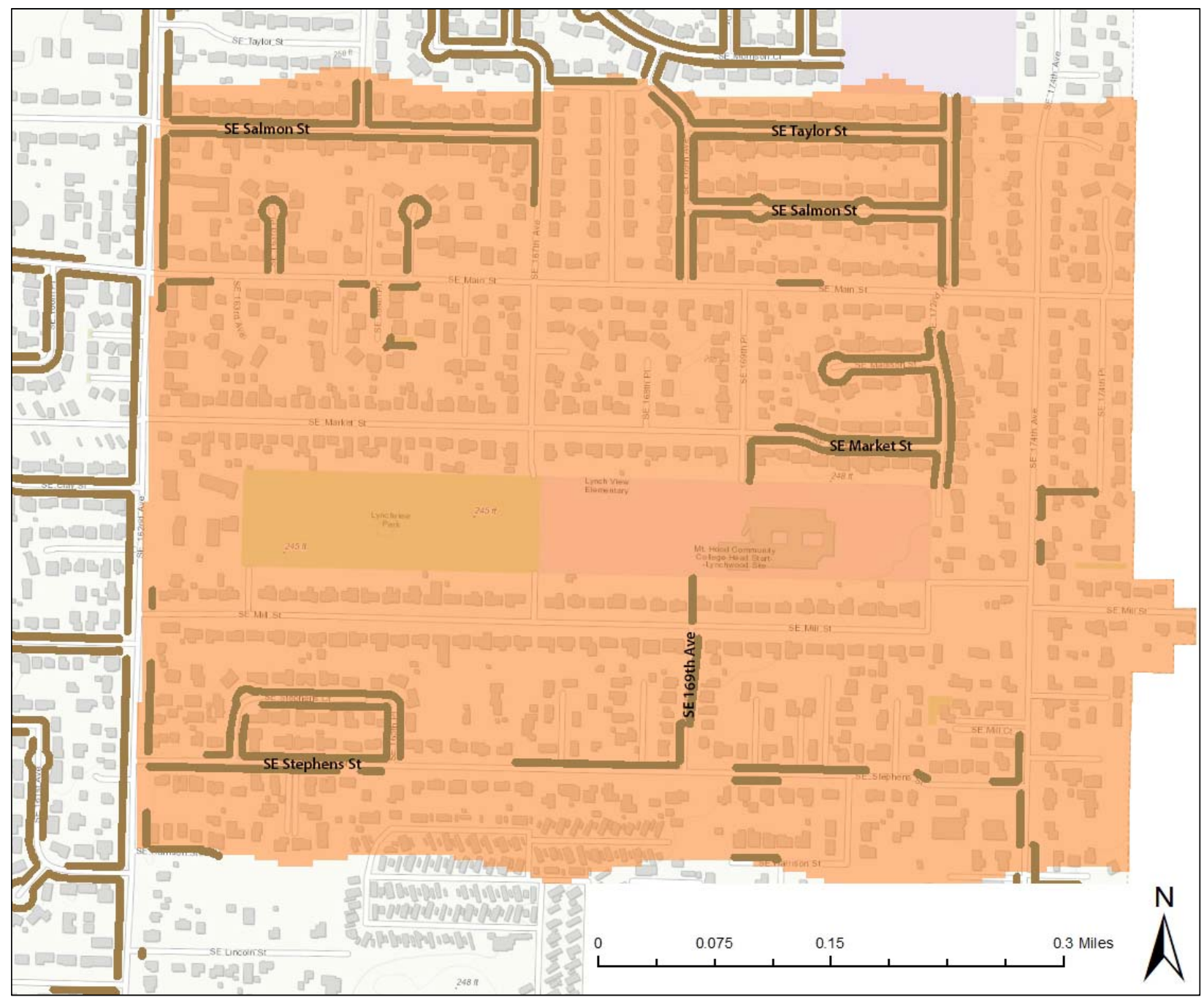

from the community itself, empower community leaders to steer the process, and attend to the cultural practices and desires of those it serves in order to prove effective.

\section{Acknowledgements}

I would like to express my sincere gratitude to Guoping Huang, Betty Izumi, Monica Cuneo, Steve Cohen, and Willis Jenkins for their instruction, inspiration, and support.

\section{References}

Alkon, A. H., Block, D., Moore, K., Gillis, C., DiNuccio, N., \& Chavez, N. (2013). Foodways of the urban poor. Geoforum, 48, 126-135. http://dx.doi.org/10.1016/j.geoforum.2013.04.021

Anguelovski, I. (2014). Alternative food provision conflicts in cities: Contesting food privilege, injustice, and whiteness in Jamaica Plain, Boston. Geoforum, 58, 184-194. http://dx.doi.org/10.1016/i.geoforum.2014.10.014

Barnes, S. L. (2005). The cost of being poor: A comparative study of life in poor urban neighborboods in Gary, Indiana. Albany: State University of New York Press. 
Bates, L. K. (2013). Gentrification and displacement study: Implementing an equitable inclusive development strategy in the context of gentrification. Portland: City of Portland, Bureau of Planning and Sustainability. Retrieved from https://www.portlandoregon.gov/bps/ $\underline{\text { article } / 454027}$

Bell, J. (2015, September 30). 5 new ways to view transit [Blog post]. Retrieved from http://blogs.esri.com/esri/arcgis/2015/09/ 30/5-new-ways-to-view-transit/

Bell, J., Mora, G., Hagan, E., Rubin, V., \& Karpyn, A. (2013). Access to bealthy food and why it matters: A review of the research. Oakland, California: PolicyLink and Philadelphia: The Food Trust. Retrieved from http://www.policylink.org/find-resources/library/ access-to-healthy-food-and-why-it-matters

Breyer, B. \& Voss-Andreae, A. (2013). Food mirages: Geographic and economic barriers to healthful food access in Portland, Oregon. Health \& Place, 24, 131-139. http://dx.doi.org/10.1016/j.healthplace. $\underline{2013.07 .008}$

Cuneo, M. (2014). Improving healthy food access in Rockwood using community voice and mapping. Retrieved from http://clfuture.org/programs/institutionalizingequity/white-papers

Fuchs, E. R., Holloway, S. M., Bayer, K., \& Feathers, A. (2014). Innovative partnership for public health: An evaluation of the New York City Green Cart Initiative to expand access to bealthy produce in low-income neighborhoods. New York: Columbia School of International and Public Affairs. Retrieved from https://sipa.columbia.edu/system/files/Green Carts Final June16.pdf

Fuller, J. (2014). Report card on racial and ethnic disparities. Portland, Oregon: Multnomah County Health Department. Retrieved from https://multco.us/file/37530/download

Goodling, E., Green, J., \& McClintock, N. (2015). Uneven development of the sustainable city: Shifting capital in Portland, Oregon. Urban Geography, 36(4), 504-527. http://dx.doi.org/10.1080/02723638.2015.1010791

Grindal, T., Wilde, P., Schwartz, G., Klerman, J., Bartlett, S., \& Berman, D. (2016). Does food retail access moderate the impact of fruit and vegetable incentives for SNAP participants? Evidence from western Massachusetts. Food Policy, 61, 59-69. http://dx.doi.org/10.1016/i.foodpol.2016.02.002

Hanser, A., \& Hyde, Z. (2014). Foodies remaking cities. Contexts, 13(3), 44-49. http://dx.doi.org/10.1177/1536504214545760

Hyde, Z. (2014). Omnivorous gentrification: Restaurant reviews and neighborhood change in the Downtown Eastside of Vancouver. City \& Community, 13(4), 341-359. http://dx.doi.org/10.1111/cico.12088

Kristina Smock Consulting. (2014). Poverty in Multnomah County. Portland, Oregon: Multnomah County Department of County Human Services, Community Services Division. Retrieved from https://multco.us/file/34343/download

Larsen, K., \& Gilliland, J. (2008). Mapping the evolution of 'food deserts' in a Canadian city: Supermarket accessibility in London, Ontario, 1961-2005. International Journal of Health Geographics, 7(16), 1-16. http://dx.doi.org/10.1186/1476-072X-7-16

LeClair, M. S., \& Aksan, A.-M. (2014). Redefining the food desert: Combining GIS with direct observation to measure food access. Agriculture and Human Values, 31(4), 537-547. http://dx.doi.org/10.1007/s10460-014-9501-y

LeDoux, T. F. \& Vojnovic, I. (2014). Examining the role between the residential neighborhood food environment and diet among low-income households in Detroit, Michigan. Applied Geography, 55, 9-18. http://dx.doi.org/10.1016/j.apgeog.2014.08.006

Luan, H., Law, J., \& Quick, M. (2015). Identifying food deserts and swamps based on relative healthy food access: A spatio-temporal Bayesian approach. International Journal of Health Geographics, 14(37), 111. http://dx.doi.org/10.1186/s12942-015-0030-8

Ocejo, R. E. (2014). Show the animal: Constructing and communicating new elite food tastes at upscale butcher shops. Poetics, 47, 106-121. http://dx.doi.org/10.1016/j.poetic.2014.10.006

Proud Ground. (n.d.). Qualify. Retrieved December 2015 from http://www.proudground.org/buy/qualify/

Raja, S., Ma, C., \& Yadav, P. (2008). Beyond food deserts: Measuring and mapping racial disparities in neighborhood food environments. Journal of Planning Education and Research, 27(4), 469-482. http://dx.doi.org/10.1177/0739456X08317461 
Robinson, J. A., Weissman, E., Adair, S., Potteiger, M., \& Villanueva, J. (2016). An oasis in the desert? The benefits and constraints of mobile markets operating in Syracuse, New York food deserts. Agriculture and Human Values. Advance online publication. http://dx.doi.org/10.1007/s10460016-9680-9

Shannon, J. (2014). What does SNAP benefit usage tell us about food access in low-income neighborhoods? Social Science \& Medicine, 107, 89-99. http://dx.doi.org/10.1016/i.socscimed.2014.02.021

Short, A., Guthman, J., \& Raskin, S. (2007). Food deserts, oases, or mirages? Small markets and community food security in the San Francisco Bay Area. Journal of Planning Education and Research, 26(3), 352-364. http://dx.doi.org/10.1177/0739456X06297795

U.S. Census Bureau. (2012a). NAICS: 445110 Supermarkets and other grocery (except convenience) stores. Retrieved from https://www.census.gov/ econ/isp/sampler.php? naicscode $=445110 \&$ naicslevel=6\#

U.S. Census Bureau. (2012b). NAICS: 445230 - Fruit and vegetable markets. Retrieved from https://www.census.gov/econ/isp/sampler.php ?naicscode $=445230 \&$ naicslevel $=6 \#$
Van Hoesen, J., Bunkley, B., \& Currier, C. (2013). A GIS-based methodology toward refining the concept of rural food deserts: A case study from Rutland County, Vermont. Journal of Agriculture, Food Systems, and Community Development, 3(2), 61-76. http://dx.doi.org/10.5304/jafscd.2013.032.006

Walker, R. E., Fryer, C. S., Butler, J., Keane, C. R., Kriska, A., \& Burke, J. G. (2011). Factors influencing food buying practices in residents of a low-income food desert and a low-income food oasis. Journal of Mixed Methods Research, 5(3) , 247267. http://dx.doi.org/10.1177/1558689811412971

Widener, M. J., Metcalf, S. S., \& Bar-Yam, Y. (2012). Developing a mobile produce distribution system for low-income urban residents in food deserts. Journal of Urban Health, 89(5), 733-745. http://dx.doi.org/10.1007/s11524-012-9677-7

Widener, M. J., Metcalf, S. S., \& Bar-Yam, Y. (2013). Agent-based modeling of policies to improve urban food access for low-income populations. Applied Geography, 40, 1-10. http://dx.doi.org/10.1016/j.apgeog.2013.01.003

Zepeda, L., \& Reznickova, A. (2013). Measuring effects of mobile markets on healthy food choices. Madison: University of Wisconsin. http://dx.doi.org/10.9752/MS142.11-2013 